\title{
Crime Prevention Strategy Of Terrorism Crime In Indonesia (Case Study In Sukoharjo)
}

\author{
Apromico ${ }^{1}$, Eko Soponyono ${ }^{2}$, and Jawade Hafiz ${ }^{3}$
}

Abstract. The terror makes rampant and perpetrators do not hesitate to hurt people even from officers and agents of Sukoharjo. This relates to the radical rapidly developing understanding and prevention that does not touch the grass roots. This study aims to analyze the characteristics of terrorism, prevention and radical ideal strategy to prevent terrorism.

Juridical sociological research method is the specification of descriptive analytical research. The use of primary and secondary data by the method of collecting data through field studies and literature. Data analysis method used is qualitative analysis. Knives used analysis of development policy theory of criminal law, Theory of Rule of Law and Theory of Crime Prevention.

The results of the study authors found the spread of radical terrorism as the entry of digital information technology so as to further spread of radical terrorists massively, Political Typology Limited was listed on terrorism, that terrorism is politics that characterized the approach of a revolutionary group, the motivation which are political or ideological. Formulation radical prevention of terrorism using national preparedness, counter-radicalization and de-radicalization. Ideal strategy terrorism prevention policies that have been implemented with the involvement of the institutions, the private sector and community groups whose influence on terrorism.

Keywords: Strategy; Prevention; Terrorism; Sukoharjo.

\section{Introduction}

Terrorism is an act of force or the threat of violence that have caused the climate of terror or fear widespread, which can cause the victim that is mass, and / or cause damage or destruction to vital objects strategic, environmental life, public facilities, or international facilities with motive of ideological, political and security disturbances. ${ }^{4}$ In the last 4 years of data, terrorist acts in 2016 include suicide bombings in Surakarta police headquarters on July 5, 2016, the Special Detachment 88 anti-terror arrests in underpass Makamhaji, Sukoharjo, on Tuesday, July 19, $2016 .^{5}$

Terrorist attacks in 2017, among others on January 14, 2017 at 14:45 AM, Attack police station on Jl. Thamrin, Central Jakarta. On 11 April 2017 attack on the police station Banyumas. Furthermore, on May 25, 2017, bomb blasts occurred twice and 3 Police

\footnotetext{
1 Student of Master of Law, Sultan Agung Islamic University (UNISSULA), Semarang Email: apromico2009@gmail.com

${ }^{2}$ Lecturer of Master of Law, Faculty of Law, UNISSULA, Semarang

${ }^{3}$ Lecturer of Master of Law, Faculty of Law, UNISSULA, Semarang

${ }^{4}$ Act No. 5 of 2018 on the Amendment of Law Number 15 Of 2003 concerning the Stipulation of Government Regulation in Lieu of Act No. 1 Of 2002 on Combating Criminal Acts of Terrorism Become Law.

${ }^{5}$ https://nasional.tempo.co/read/788786/densus-tangkap-hasan-di-sukoharjo-diduga-terkait-bomsolo/full\&view=ok
} 
officers killed in the Terminal Kampung Melayu, East Jakarta. ${ }^{6}$ The attack in the North Sumatra Police took place on June 25, 2017 at 03.00 pm. Terrorists slay his victim, Aiptu Martua Sigalingging sadistically. After injuring the victim with multiple stab wounds, perpetrators burn victim's body. ${ }^{7}$

The incident on the Special Detachment (Densus) 88 Antiterror arrested two suspected terrorists on Monday, May 29, 2017. The arrest was made at two locations, namely in Sukoharjo and Karanganyar, Central Java. Initial T terrorist suspects, residents of RT 02/06 Watusambang, Plumbon village, District Tawangmangu, Karanganyar. While in Sukoharjo, Densus 88 arrested in the village street Bugel Village, District Polokarto, Sukoharjo. Detachment 88 arrested a man initial R as B which is secured in Cibubur, West Java. The perpetrator allegedly linked to the bombing in Terminal Kampung Melayu. ${ }^{8}$

2018 bombings at three churches in Surabaya in Surabaya Mapolrestabes. In Maporestabes Surabaya, a bomb exploded there the morning of May 14, 2018. Suicide bombing in Rusunawa Wonocolo occurred on May 13, 2018 night, on the 5th floor of Block B No. 2, as well as unrest napiter who break prison cells causing five police officers and one prisoner died. In the June 4, 2019 at 22:30 AM happen in Kartasura Police Station, Sukoharjo. Performers are Rofik Asharudin (22), a resident of Kranggan Kulon, Kartasura Sukoharjo district. ${ }^{9}$ Special Detachment (Densus) 88 Anti-Terror Police Headquarters raided two homes unexpectedly terrorist located Waringinrejo, Sukoharjo on the day Wednesday, October 16, 2019. The search was in Gang Murai, Waringinrejo, Cemani, Grogol, Sukoharjo. Where most of the terrorists in Central Java, leading to Sukoharjo district.

Combating terrorism in Indonesia, the government initially put forward options violent approach (hard approach) is to chase and arrest the perpetrators. Since the Reformation era government uses law enforcement strategies (law enforcement led strategy). ${ }^{10}$ Currently, the strategy used a combination of "hard approach" and "soft approach". Treatment with a hard approach carried out by law enforcement strategy through "due process of law" was successful in reducing terrorism. Strategies hard approach is deemed not to touch the root of the problems associated with the mindset and ideology.

To complement the hard approach strategy, the government is also using the soft strategy approach is through the development of prevention and deterrence of radical terrorist ideology. ${ }^{11}$ Under these conditions, the authors are interested in doing research with the title "Crime Prevention Strategy Of Terrorism Crime In Indonesia (Case Study In Sukoharjo)". The problems that will be investigated in this paper is as

\footnotetext{
${ }^{6}$ https://nasional.tempo.co/read/887298/ini-berbagai-serangan-teroris-pada-polisi

7 https://news.detik.com/berita/d-3541617/teror-di-polda-sumut-diduga-terkait-penangkapan-3teroris-di-medan

8 https://news.detik.com/berita/d-3513982/densus-88-tangkap-2-terduga-teroris-di-sukoharjo-dankaranganyar

9 https://regional.kompas.com/read/2019/06/07/18204921/5-fakta-bom-bunuh-diri-di-sukoharjo-

pelaku-berbaiat-dengan-isis-lewat-medsos?page=all

${ }^{10}$ Karnavian, Muhammad Tito, Peran Polri Dalam Penanganan Terorisme di Indonesia, Scientific Oration of Police Science Police Science (Jakarta: 2017), p. 30.

${ }^{11}$ Ibid, p. 34
} 
follows: How The Radical Characteristics Of Terrorism That Occurred in Sukoharjo?; How The Analysis And Formulation Of Prevention Of Criminal Acts Of Terrorism in Sukoharjo?; How Ideal Strategy Crime Prevention of Terrorism in Indonesia?

\section{Research Methods}

The approach used in this study is a sociological juridical approach to identify and conceptualize the system of law in real life, sociological juridical approach aims to acquire legal knowledge empirically by the way go directly to the object. Descriptive because this study is expected to obtain a clear picture, detailed and systematic.

The selected research focus on the problem in Sukoharjo district is in accordance with the density of activity and the short time of the study. Data used in this study are primary data obtained through interviews (interviews) freely guided. Secondary data were obtained from the research literature. Collection methodology using interview techniques, then the data- collecting data from interviews and observations with regard to the handling of terrorism.

Data analysis method used is a qualitative method. Qualitative data analysis is a research method that produces descriptive data analytical, namely what is stated by the respondent in writing or orally, and also the real behavior researched and studied as a whole. Once the data analysis is complete, the results will be presented descriptively, ie by telling and describing what is in accordance with the problems studied.

\section{Results And Discussion}

\subsection{Characteristics of Radical Terrorists Which Happens in Sukoharjo}

Characteristics of the article authors presented the findings obtained from the results of study conducted in Sukoharjo district. The spread of radical characterized by those who opposed the existing normative order, do not accept anyone else except from the Koran friend or group.The reaction to this condition is very evident and easily visible with his attitude when finding strangers or foreigners from their group. Understand radical learned not limited to the study of religion but had to be doctrinal against the rejection of government policy and the beliefs of radical or ideological program of the truth that they carry.

The county has been detected Sukoharjo ISIS support groups and citizens who had joined a group ISIS in Syria". Distribution patterns of terrorist radical understanding is one way that is very massive and easy to do. Distribution method is done by open and in what way and anywhere. This happens because the terrorists have already faced the real forms of resistance more than just preaching the radical. Therefore, the spread of radical terrorists understand more diverse and its frontal. Factors sociology society more open to new understanding, is considered to be the cause of radicalism continues to grow.

Those who opposed the political and social world order by placing themselves would not accept anyone else except from their group. Radicals have thought difficult to change because of the false doctrine and closed to the truth they believe in and are 
willing to do anything, even sacrifice life to defend it in the name of religion. In fact, they are doing is against religion.

Typology of acts Political terrorism Limited classify terrorism, namely terrorism true political nature characterized by the approach of a revolutionary group. Acts of terrorism carried out by motivations which are political or ideological but is not part of a joint campaign with the aim to control a country. Understand the influence of radicals can be detected and viewed in stages namely Exposed, sympathizers, Radical and Terrorism.

\subsection{Analysis and Counter Terrorism Formulation Which Happens In Sukoharjo.}

Terrorism is a crime forms by using methods of violence committed by a person or group of people aimed at civilian targets, public as well as his wealth for political purposes with different motivations. ${ }^{12}$ Act No. 5 of 2018, supported by the Sociological Basis of Terrorism in Indonesia has grown massively and causing fear among the people that have an impact on the political, economic, social, cultural, security and public order.

Expansion within the meaning of terrorism in order to provide more space for law enforcement officers and special handling in dealing with terrorism. The definition of terrorism, policy formulation marked by changes and additions in the formulation of a crime, the formulation of the fault or criminal liability as well as criminal and sentencing formula, the expansion and the addition of the classification of criminal acts of terrorism as well as the weighting in judging terms.

According to Perlgut the research has identified in four distinct categories of crime and its prevention (1) The corrective prevention efforts to prevent crime by improving the social conditions that lead to crime. (2) Prevention through penalty to use the police to prevent crime through lawyers, court police, prison and legal system. (3) Prevention of mechanical emphasis on hardware such as locks, doors and grilles. (4) Prevention of manipulating environmental design of buildings and the relationship between the building and its environment is reduced opportunities for crime. ${ }^{13}$

In the theory of legal certainty for the handling of Terrorism has fulfilled the identity value, is as follows ${ }^{14}$ Principle legal certainty (Rechtmatigheid). The principle of judicial review of the corner, where the perpetrators of criminal acts subject to Article in the regulation of the crime of terrorism. The principle of legal justice (Gerectigheit). This principle is reviewing from a philosophical angle, where justice is equal rights for all people in front of the court. The principle of legal expediency (Zwechmatigheid or Doelmatigheid or utility) where the legal purpose realistic approach is legal certainty and legal expediency.

Act No. 5 of 2018 is expected to be optimal in the implementation of the prevention of criminal acts of terrorism. Prevention optimally performed involving relevant

\footnotetext{
${ }^{12}$ Muzadi, KH. A Hasyim, 2004, Kejahatan Terorisme Perspektif Agama, HAM dan Hukum, PT. Refika Aditama, Bandung, p.59.

${ }^{13}$ Geason Susan, 1988, Crime Prevention Theory and Practice, Canberra, Australia Institute Criminology, p. 4.

${ }^{14}$ Dwika, "Keadilan dari Dimensi Sistem Hukum", (http://hukum.kompasiana.com, accessed May 21, 2019).
} 
ministries or agencies and all components of the nation through the efforts of national preparedness, counter-radicalization and de-radicalization which is coordinated by the National Counter Terrorism Agency in accordance with Article 43A paragraph 3. Furthermore, it can explain of preventive measures as follows:

- National Preparedness in Sukoharjo district.

- Cons Radicalization in Sukoharjo district.

- Deradicalization in Sukoharjo district.

The process of prevention of Terrorism with the formulation of Act No.5 of 2018 in accordance with the theory of Daniel Milled call essence, it can be seen that the concept of prevention can be made to serve a useful purpose for the government, professions, and finally to the state itself. This is all due to the inherent attractiveness and clear of prevention in association with social problems, because interpreting the word flexible, allowing it to be stretched into a number of possible reasons and motives, just practical. ${ }^{15}$

According to the Theory of Legal Policy as one alternative to crime prevention, then criminal law policy is part of the criminal policy. Thus in the context of an integrated crime prevention, the policy of criminal law (penal approach) in development must always consider tackling another alternative, namely non penal approach for the reduction of crime by using means other than criminal law.

Prevention of criminal acts of terrorism carried out in accordance with Act No. 5 of 2018 in accordance with the conception of the idea of an integral approach and policy approaches and values. Where an integral approach between the policy of penal and non-penal. Rational efforts to control or solve crimes (criminal politics) are certainly not just use penal (criminal law), but can also use the means of non-penal. Efforts nonpenal This could include a very wide field once in the social policy sector.

According to Susan Geason, be successful, crime prevention programs require entities providing the resources and enough motivation to implement. This is most likely to occur where the agency believes the measures will save money. Crime-prevention measures could also be sold at the show that they will do the actual increase has been improved; for example if the doors and windows must be replaced, the new doors and windows it may also come from a thief and a crook of the same. Very often, the steps can be successfully implemented with little cost as part of a broader improvement program. $^{16}$

\subsection{Ideal Strategy Crime Prevention of Terrorism}

Combating terrorism that combines hard and soft approach is an ideal strategy but the implementation of the necessary in-depth discussion and how implementation and constraints must be kept updated. In conjunction with the hard approach, Indonesia has issued Act No. 5 of 2018 on Combating Terrorism and Government Regulation No. 77 Of 2019 on the Prevention of Terrorism in order to strengthen counter-terrorism efforts in Indonesia. It has also endorsed the Joint Regulations on the Handling of

\footnotetext{
${ }^{15}$ Gilling Daniel, 1997, Crime Prevention Theory, Policy and Politics, London, UCL Press, p. 11

${ }^{16}$ Geason Susan, 1988, Crime Prevention Theory and Practice, Canberra, Australia Institute Criminology, p. 12
} 
radicalism in the framework of strengthening the National Insights On the State Civil Apparatus expand prevention efforts Terrorism to the grass roots.

Ideal strategy approach refers to a series of crime prevention strategies that have been implemented by individuals, communities, businesses and non-governmental organizations to target a wide range of social and environmental factors. Analysis ideal prevention strategy criminal acts of terrorism in the form of a policy that has been implemented is the involvement of government institutions, private sector and community groups that have an influence on the rise of terrorism

The policy among others ${ }^{17}$ political policies related to the prevention of terrorism, economic policy related to the prevention of terrorism, Prevention through the viewpoint of ideology accordance with Motif carried out by terrorists, Participated of Government Institutions, Private Sector and Community Groups, Form mitigation or prevention of the private sector, society positions in its role to prevent acts of terrorism, factors affecting the emergence of terrorism, Actor terrorism and the surrounding communities of terrorism, law enforcement is responsible for counterterrorism.

The results of the study authors ideal prevention strategy criminal act of terrorism that is a policy that has been implemented the involvement of government, private and community groups that influence the emergence of terrorism. Her focus on the political, economic, ideological, local government, private sector, and community groups.

\section{Closing}

\subsection{Conclusion}

Based on the results of research and discussion related crime prevention strategy of terrorism in Indonesia (Sukoharjo case study), the researchers draw conclusions as follows:

- Characteristics of radical terrorism found in Sukoharjo district prone to the spread of radical. Factors sociology society more open to understand the new, so it can be classified typology of Limited Political terrorism, namely terrorism of a political nature that marked the approach of a revolutionary group, performed with motivations are political or ideological but is not part of a joint campaign, with purpose to control a country.

- Formulation prevention of criminal acts of terrorism in Sukoharjo

- National preparedness in Sukoharjo done by mapping areas vulnerable to understand radical terrorism.

- Cons counter radicalization in Sukoharjo district radicals, interpreted as a process that is integrated, systematic, and continuous.

- Deradicalization in Sukoharjo district, the Ministry or the relevant institutions to carry out the implementation of de-radicalization.

\footnotetext{
${ }^{17}$ Effendi Umar, 2017Aksi Kolektif Mencegah Terorisme (Studi Preventif Analisi Kebijakan Anti Teror di Indonesia Dalam Persepektif Collection Action), Pensil-324, Jakarta, p.231
} 
- Ideal strategy prevention of criminal acts of terrorism against the results of the study resulted in a policy that has been implemented is the involvement of government institutions, private sector and community groups that influence the emergence of terrorism. The focus of its policies, among others (1). Political policies related to terrorism prevention. (2). Economic policy related terrorism prevention. (3). Prevention through the viewpoint of ideology accordance motive of the terrorists. (4). Participated of Government, private sector and community groups. (5). Forms reduction or prevention of the private sector. (6). Optimizing society positions in its role to prevent acts of terrorism. (7). Pressing the factors that influence the emergence of terrorism. (8). Actors Monitoring terrorism and the surrounding communities of terrorism. (9).

\subsection{Suggestion}

- Characteristics of radical terrorists in Sukoharjo district

- The need for routine monitoring of all stakeholders

- Optimal supervision and cooperation with the ministry of local government and police,

- Strengthen counter terrorism by radical synergy with institutions of local government and relevant ministries.

- Formulation prevention of criminal offenses in Sukoharjo.

- In The need for legal standing in the form of local government departments to enhance the role of local government in coordination with all stakeholders and the public.

- Prevention is done in harmony with: National preparedness is done by mapping areas vulnerable accurate; Cons counter radicalization in Sukoharjo district radicals. Implementation of radical counter on target; Deradicalization in Sukoharjo, Increasing Role of Local Government and the Ministry of the relevant institutions to carry out the implementation of the de-radicalization including ministries of Justice, Public Prosecution Service and Police. Implementation is always FKPT Central Java province and BNPT.

\section{References}

Book

[1] Muzadi, KH. A Hasyim, 2004, Kejahatan Terorisme Perspektif Agama, HAM dan Hukum, PT. Refika Aditama, Bandung.

[2] Geason Susan, 1988, Crime Prevention Theory and Practice, Canberra,Australia Institute Criminology, h. 4.

[3] Gilling Daniel, 1997, Crime Prevention Theory, Policy and Politics, London, UCL Press

[4] Effendi Umar, 2017, Aksi Kolektif Mencegah Terorisme (Studi Preventif Analisi Kebijakan Anti Teror di Indonesia Dalam Persepektif Collection Action), Pensil-324, Jakarta 
Journals

[1] Karnavian, Muhammad Tito, Peran Polri Dalam Penanganan Terorisme di Indonesia, Scientific Oration of Police Science Police Science (Jakarta : 2017 )

[2] Dwika, "Keadilan dari Dimensi Sistem Hukum", (http://hukum.kompasiana.com, accessed May 21, 2019).

[3] Kapur Radhika. Dr, Crime Prevention Strategies, Jurnal

Constitution

[1] Act No. 5 of 2018 on the Amendment of Act No. 15 Of 2003 concerning the Stipulation of Government Regulation in Lieu of Act No. 1 Of 2002 on Combating Criminal Acts of Terrorism Become Law.

Website

[1] https://nasional.tempo.co/read/788786/densus-tangkap-hasan-di-sukoharjodiduga-terkait-bom-solo/full\&view=ok

[2] https://nasional.tempo.co/read/887298/ini-berbagai-serangan-teroris-pada-polisi

[3] https://news.detik.com/berita/d-3541617/teror-di-polda-sumut-diduga-terkaitpenangkapan-3-teroris-di-medan

[4] https://news.detik.com/berita/d-3513982/densus-88-tangkap-2-terduga-terorisdi-sukoharjo-dan-karanganyar

[5] https://regional.kompas.com/read/2019/06/07/18204921/5-fakta-bom-bunuhdiri-di-sukoharjo-pelaku-berbaiat-dengan-isis-lewat-medsos?page=all 